\title{
Analysis of The Relationship between Blood Groups and Lung Cancer Risk Depending on Histology
}

\author{
Canan EREN [i] ${ }^{1}$, Ayten GÜNER AKBIYIK ${ }^{2}$, Ilker Nihat ÖKTEN 國 ${ }^{3}$
}

\begin{abstract}
Aim: Blood group antigens are the first genetic markers discovered. ABO blood groups which are expressed on red blood cell membranes are reported to be associated with malignancy risk. The present study aimed to investigate whether there is an association between blood groups and patients with lung cancer.

Material and Methods: In our study, it was reviewed 587 patients with lung cancer whose ABO/Rh blood types were serologically confirmed. Patients were classified according to blood groups $(\mathrm{O}, \mathrm{A}, \mathrm{B}, \mathrm{AB}), \mathrm{Rh}$ factor $(+,-)$ and histological types of lung cancer as Non-small cell lung carcinoma (NSCLC) and Small cell lung carcinoma (SCLC). The adenocarcinoma (AC) and squamous carcinoma (SC) as subtypes of NSCLC were recorded. The relationship of $\mathrm{ABO} / \mathrm{Rh}$ blood groups with clinical features, such as age, sex and histological subtype were evaluated.

Results: There was no significant association between pathological results and blood groups O, A, B and AB. SCLC patients had significantly higher frequency of blood type B Rh (-) when compared to NSCLC patients.

Conclusion: We observed an association between risk of lung cancer and ABO blood groups. Although the Rh factor is not effective by itself, patients with the B Rh (-) blood group may have a higher risk than SCLC. Examining the relationship of blood group subtypes with lung cancer cells at the molecular level would be useful to clarify the relationship between lung cancer and blood groups.
\end{abstract}

Keywords: Blood group antigens; lung cancer; antigen

\section{ÖZ}

Kan Grupları ile Akciğer Kanseri Riski Arasındaki İlişkilerin Histolojiye Bağlı Analizi

Amaç: Kan grubu antijenleri, keşfedilen ilk genetik belirteçlerdir. Kırmızı kan hücre zarlarından eksprese edilen ABO kan gruplarının çeşitli çalışmalarda malignite riski ile ilişkili olduğu gösterilmiştir. Bu çalışmanın amacı, kan grupları ile akciğer kanseri arasında bir ilişki olup olmadı̆̆ını araştırmaktır.

Gereç Yöntemler: Çalışmamızda ABO ve Rh kan grubu serolojik olarak doğrulanmış 587 akciğer kanserli hasta gözden geçirildi. Hastalar kan gruplarına (O, A, B, AB), Rh faktörü (+, -) ve histolojik akciğer kanseri tiplerine göre [Küçük Hücreli Dışı Akciğer kanseri (KHDAK) ve Küçük Hücreli Akciğer Kanseri (KHAK)] sınıflandırıldı. KHDAK'nin adenokarsinom (AK) ve skuamöz karsinom (SK) alt tipleri kaydedildi. ABO / Rh kan gruplarının yaş, cinsiyet ve histolojik alt tip gibi klinik özelliklerle ilişskisi değerlendirildi.

Bulgular: Patolojik analiz sonucu ile O, A, B ve AB kan grupları arasında anlamlı bir ilişki bulunmadı. Çalışmada KHAK'li olgularda B Rh (-) kan grubuna sahip olan hastaların oranı, KHDAK'li olanlardan daha yüksek bulundu.

Sonuç: Akciğer kanseri riski ile ABO kan grupları arasında bir ilişki olduğu görüldü. Rh faktörü tek başına etkili olmamakla beraber B Rh (-) kan grubuna sahip olan hastalar KHAK açısından daha fazla riske sahip olabilir. Kan grubu alt tiplerinin akciğer kanseri hücreleriyle moleküler düzeyde ilişkisinin incelenmesi, akciğer kanseri ve kan grupları arasındaki ilişkiyi açıklığa kavuşturmak için yararlı olacaktır.

Anahtar Kelimeler: Kan grubu antijenleri; akciğer kanseri; antijen

1 Marmara University Pendik Training and Research Hospital, Medical Microbiology and Blood bank

2 Istanbul Professor Dr Suleyman Yalcin City Hospital, Thoracic Surgery Clinic

3 Istanbul Professor Dr Suleyman Yalcin City Hospital, Medical Oncology Clinic

Sorumlu Yazar / Corresponding Author: Ayten Guner AKBIYIK, e-mail: aytenguner@yahoo.com

Geliş Tarihi / Received: 25.01.2021, Kabul Tarihi / Accepted: 15.05. 2021 


\section{INTRODUCTION}

Lung cancer is the most common and fatal cancer type in developed countries. Lung cancer is responsible for $12.8 \%$ of all cancer cases and $17.8 \%$ of all deaths due to cancer worldwide $(1,2)$. Various studies were conducted on incidence and prognostic factors of lung cancer. There are studies indicating that blood group antigens may have prognostic importance for incidence of lung cancer. Smoking still remains the most significant risk factor for development of lung cancer (3). Apart from this, environmental carcinogens, ionizing radiation, some genetic factors and inherited predisposition are other potential risk factors (4).

Blood group antigens are the first genetic markers discovered. The correlation of $\mathrm{ABO}$ blood groups with certain diseases, including infections, vascular and malignant diseases, was demonstrated (5). Association between $\mathrm{ABO} / \mathrm{Rh}$ blood groups and incidence of some cancer types (i.e. gastric, pancreatic, ovarian, colorectal and renal cancers) were detected. Some studies were conducted to review the relation of lung cancer risk with blood groups as well as survival rates; however, the number of studies are less to provide reliable data (6-19). The correlation between histological types of lung cancer and blood types is not yet clarified. The present study is aimed to review the association between $\mathrm{ABO} / \mathrm{Rh}$ blood groups and lung cancer.

\section{MATERIAL AND METHODS}

The present study was conducted retrospectively on 587 patients with lung cancer, including 118 females (20.1\%) and 469 males (79.9\%), who were followed and treated. The patients with cancer on a different body region and with rare cancer types were excluded.

Patients were classified according to blood groups $(\mathrm{O}, \mathrm{A}$, $\mathrm{B}, \mathrm{AB})$ and $\mathrm{Rh}$ factor $(+,-)$. The histopathological subtypes were recorded as non-small cell lung carcinoma (NSCLC) and small cell lung carcinoma (SCLC). The adenocarcinoma (AC) and squamous carcinoma (SC) as subtypes of NSCLC were recorded. The relationship of $\mathrm{ABO} / \mathrm{Rh}$ blood groups with clinical features, such as age, sex and histological subtype were evaluated.

\section{Statistical Analyses}

NCSS (number cruncher statistical system) 2007 (Kaysville, Utah, USA) program was used for statistical analyses. Descriptive statistical methods (mean, standard deviation, median, frequency, percentage, minimum and maximum) were used to evaluate the data of the study. Qualitative data comparison was performed using Pearson's chi-square test, Fisher's exact test and FisherFreeman-Halton test. Statistical significance was accepted as $\mathrm{p}<0,05$.

The study was approved by the institutional review board committee (09/10/2019; 2019/0365) and conducted according to Helsinki Declaration.

\section{RESULTS}

The average age of patients were $64.92 \pm 6.99$ years ranging from 32 to 86 years old.

Age, gender, blood group distribution and histological types of lung cancer were presented in Table 1.
Table 1. Distribution of descriptive characteristics

\begin{tabular}{|c|c|c|}
\hline & & n (\%) \\
\hline \multirow[t]{2}{*}{ Age (years) } & Min-Max (Median) & $32-86(65)$ \\
\hline & Mean \pm sd & $64.92 \pm 6.99$ \\
\hline \multirow[t]{2}{*}{ Gender } & Female & $118(20.1)$ \\
\hline & Male & $469(79.9)$ \\
\hline \multirow[t]{8}{*}{ Blood group } & ORh (-) & $16(2.7)$ \\
\hline & ORh $(+)$ & $187(31.9)$ \\
\hline & A Rh (-) & $33(5.6)$ \\
\hline & A Rh (+) & $235(40.0)$ \\
\hline & B Rh (-) & $5(0.9)$ \\
\hline & B Rh (+) & $62(10.6)$ \\
\hline & AB Rh (-) & $6(1.0)$ \\
\hline & $\mathrm{AB} \mathrm{Rh}(+)$ & $43(7.3)$ \\
\hline \multirow[t]{4}{*}{ Blood group } & Group O & $203(34.6)$ \\
\hline & Group A & $268(45.7)$ \\
\hline & Group B & $67(11.4)$ \\
\hline & Group $\mathrm{AB}$ & $49(8.3)$ \\
\hline \multirow[t]{2}{*}{$\mathbf{R h}$} & $(-)$ & $60(10.2)$ \\
\hline & $(+)$ & $527(89.8)$ \\
\hline \multirow[t]{4}{*}{$\begin{array}{l}\text { Pathology } \\
\text { result }\end{array}$} & $\begin{array}{l}\text { Small Cell Lung Ca } \\
\text { (SCLC) }\end{array}$ & $114(19.4)$ \\
\hline & $\begin{array}{l}\text { Non-small Cell Lung Ca } \\
\text { (NSCLC) }\end{array}$ & $473(80.6)$ \\
\hline & Adenocarcinoma (AC) & $308(65.1)$ \\
\hline & $\begin{array}{l}\text { Squamous carcinoma } \\
\text { (SC) }\end{array}$ & $165(34.9)$ \\
\hline
\end{tabular}

There was no statistically significant association observed between pathological results and blood groups $0 \mathrm{Rh}(-)$, $\mathrm{O} \mathrm{Rh}(+), \mathrm{A} \mathrm{Rh}(-), \mathrm{A} \mathrm{Rh}(+), \mathrm{B} \mathrm{Rh}(+), \mathrm{AB} \mathrm{Rh}(-)$ and $\mathrm{AB} \mathrm{Rh}(+)(\mathrm{p}>0,05)$. A statistically significant association was detected between pathological results and blood group $\mathrm{B} \mathrm{Rh}(-)(\mathrm{p}=0,006 ; \mathrm{p}<0,01)$, and there were more patient with blood group B Rh (-) in SCLC group than patient in NSCLC group (Table 2).

There was no significant association observed between pathological results and blood groups $\mathrm{O}, \mathrm{A}, \mathrm{B}$ and $\mathrm{AB}$ $(\mathrm{p}>0,05)$. Furthermore, there was not any statistically significant association between pathological results and $\mathrm{Rh}$ factor $(\mathrm{p}>0,05)$ (Table2).

There was not any statistically significant association between pathological results and blood groups $\mathrm{O} \mathrm{Rh}(-)$, $\mathrm{O} \mathrm{Rh}(+), \mathrm{A} \mathrm{Rh}(-), \mathrm{B} \mathrm{Rh}(+), \mathrm{AB} \mathrm{Rh}(-)$ and $\mathrm{AB} \mathrm{Rh}(+)$ $(\mathrm{p}>0,05)$. A statistically significant association was detected between pathological results and blood group $B$ $\mathrm{Rh}(-)(\mathrm{p}=0,004 ; \mathrm{p}<0,01)$. The number of patient with blood type B Rh (-) was higher in the SCC group than AC and SC subgroups. A statistically significant association was found between pathological results and blood group $\mathrm{AB} \mathrm{Rh}(-)(\mathrm{p}=0,016 ; \mathrm{p}<0,05)$. The rate of blood type $\mathrm{AB} \mathrm{Rh}(-)$ was higher in the $\mathrm{AC}$ and $\mathrm{SCC}$ group than SC subgroup (Table 3). 
Table 2. The association of blood group with two histological subtype of lung cancer

\begin{tabular}{|c|c|c|c|c|}
\hline & \multicolumn{2}{|c|}{ Pathology result } & \multirow[t]{2}{*}{$p$} \\
\hline & & NSCLC & SCLC & \\
\hline \multirow{8}{*}{$\begin{array}{l}\text { Blood } \\
\text { group } \\
\text { (with } \\
\text { Rh } \\
\text { factor) }\end{array}$} & O Rh (-) & $14(3.0)$ & $2(1.8)$ & ${ }^{a} 0.749$ \\
\hline & $\mathrm{O} \mathrm{Rh}(+)$ & 154 (32.6) & $33(28.9)$ & ${ }^{b} 0,458$ \\
\hline & A Rh (-) & $27(5.7)$ & $6(5.3)$ & $b^{b} 0,853$ \\
\hline & A Rh (+) & $183(38.7)$ & $52(45.6)$ & ${ }^{b} 0,176$ \\
\hline & B Rh (-) & $1(0.2)$ & $4(3.5)$ & ${ }^{a} 0,006 * *$ \\
\hline & B Rh (+) & $52(11.0)$ & $10(8.8)$ & ${ }^{b} 0,488$ \\
\hline & AB Rh (-) & $6(1.3)$ & $0(0)$ & ${ }^{a} 0.602$ \\
\hline & $\mathrm{AB} \mathrm{Rh}(+)$ & $36(7.6)$ & $7(6.1)$ & ${ }^{b} 0,589$ \\
\hline \multirow{4}{*}{$\begin{array}{l}\text { Blood } \\
\text { group } \\
\text { (without } \\
\text { Rh } \\
\text { factor) }\end{array}$} & Group O & $168(35.5)$ & $35(30.7)$ & $b^{b} 0,332$ \\
\hline & Group A & $210(44.4)$ & $58(50.9)$ & ${ }^{b} 0,212$ \\
\hline & Group B & $53(11.2)$ & $14(12.3)$ & ${ }^{b} 0,746$ \\
\hline & Group AB & $42(8.9)$ & $7(6.1)$ & ${ }^{b} 0,343$ \\
\hline \multirow[t]{2}{*}{$\mathbf{R h}$} & - & $48(10.1)$ & $12(10.5)$ & \multirow[t]{2}{*}{${ }^{b} 0,905$} \\
\hline & + & 425 (89.9) & $102(89.5)$ & \\
\hline
\end{tabular}

${ }^{\mathrm{a}}$ Fisher's Exact Test, ${ }^{\mathrm{b}}$ Pearson's Chi-Square Test $* * \mathrm{p}<0,01$

There was not any significant association between pathological results and blood groups $\mathrm{O}, \mathrm{B}$ and $\mathrm{AB}$ $(\mathrm{p}>0,05)$. A statistically significant association was detected between pathological results and blood group A $(p=0,010 ; p<0,05)$. The rate of blood type A was higher in AC and SCC groups than SC group (Table 3).

Table 3. The association between lung cancer and three histological subtype

\begin{tabular}{|c|c|c|c|c|}
\hline \multirow[b]{2}{*}{$\begin{array}{l}\text { Blood } \\
\text { group }\end{array}$} & \multicolumn{3}{|c|}{ Pathology result } & \multirow[b]{2}{*}{$p$} \\
\hline & $\begin{array}{c}\text { Adeno } \\
\text { carcinom } \\
\mathrm{a}(\mathrm{n}=308)\end{array}$ & $\begin{array}{c}\text { Squamous } \\
\text { carcinoma } \\
(\mathrm{n}=165)\end{array}$ & $\begin{array}{c}\text { Small Cell } \\
\mathrm{Ca}\end{array}$ & \\
\hline $0 \mathrm{Rh}(-)$ & $10(3.2)$ & $4(2.4)$ & $2(1.8)$ & ${ }^{c} 0.790$ \\
\hline $0 \mathrm{Rh}(+)$ & $92(29.9)$ & $62(37.6)$ & 33 (28.9) & ${ }^{b} 0,176$ \\
\hline A Rh (-) & $16(5.2)$ & $11(6.7)$ & $6(5.3)$ & ${ }^{b} 0.811$ \\
\hline A Rh (+) & 135 & $48(29.1)$ & $52(45.6)$ & ${ }^{b} 0.003^{* * *}$ \\
\hline B Rh (-) & $0(0)$ & $1(0.6)$ & $4(3.5)$ & ${ }^{c} 0.004^{* * * *}$ \\
\hline B Rh (+) & $30(9.7)$ & $22(13.3)$ & $10(8.8)$ & ${ }^{b} 0.382$ \\
\hline AB Rh (-) & $1(0.3)$ & $5(3.0)$ & $0(0)$ & ${ }^{c} 0.016^{*}$ \\
\hline AB Rh (+) & $24(7.8)$ & $12(7.3)$ & $7(6.1)$ & ${ }^{b} 0,846$ \\
\hline Group O & 102 & $66(40.0)$ & $35(30.7)$ & ${ }^{b} 0,204$ \\
\hline Group A & 151 & $59(35.8)$ & $58(50.9)$ & ${ }^{b} 0.010^{*}$ \\
\hline Group B & $30(9.7)$ & $23(13.9)$ & $14(12.3)$ & ${ }^{b} 0.363$ \\
\hline Group AB & $25(8.1)$ & $17(10.3)$ & $7(6.1)$ & ${ }^{b} 0.489$ \\
\hline$(-)$ & $27(8.8)$ & $21(12.7)$ & $12(10.5)$ & ${ }^{b} 0.400$ \\
\hline$(+)$ & 281 & $144(87.3)$ & $102(89.5)$ & \\
\hline
\end{tabular}

${ }^{b}$ Pearson's Chi-Square Test ${ }^{c}$ Fisher Freeman Halton Test ${ }^{*} \mathrm{p}<0,05$ $* * \mathrm{p}<0,01$

There was not any statistically significant association between pathological results and $\mathrm{Rh}$ factor $(\mathrm{p}>0,05)$.

\section{DISCUSSION}

ABO blood group gene is mapped at the chromosome $9 q 34$ and encodes blood group antigens related to glycotransferases (20). ABO antigens are also expressed on the surface of many cells other than erythrocytes, like epithelial cells, including urothelium, gastrointestinal, mucosa and lung. Alterations on the cell surface structures by blood group antigens may lead to changes in the interactions in between cells or cells and extracellular matrix. These changes are considered to be important for tumour development (21). Recent studies reported an association between $\mathrm{ABO}$ blood group and the risk of various epithelial cancers. Non-O blood group increases the risk of cancer, including pancreatic, gastric, ovarian, kidney, colorectal and dermal carcinomas (22-25).

In the present study, when we classified the patients according to the histology of the lung cancer as NSCLC and SCLC, a statistically significant association was detected between pathological results and group B Rh (-) $(\mathrm{p}=0,006 ; \mathrm{p}<0,01)$, and the rate of group B $\mathrm{Rh}(-)$ in the patients with SCLC was higher than those with NSCLC. There was not any statistically significant association between pathological results and blood groups $\mathrm{O}, \mathrm{A}, \mathrm{B}$ and $\mathrm{AB}$ when $\mathrm{Rh}$ factor was excluded $(\mathrm{p}>0,05)$. Furthermore, there was not any statistically significant association between pathological results and $\mathrm{Rh}$ factor in terms of $\mathrm{Rh}$ factor $(\mathrm{p}>0,05)$.

Oguz et al. stated that they did not find any relationship between ABO-RH blood groups and NSCLC and SCLC groups. Moreover, for NSCLC histological subtypes, there was no significant difference was detected for neither blood group analysis nor Rh status (18). Evaluation for NSCLC subtypes (AC and SCC) in the present study revealed a statistically significant association between pathological results and blood group A Rh (+) $(\mathrm{p}=0,003 ; \mathrm{p}<0,01)$. We found the rate of blood type A Rh (+) higher in the AC and SCLC subgroups than SC group. Furthermore, we detected a statistically significant association between pathological results and blood group $\mathrm{AB} \mathrm{Rh}(-)(\mathrm{p}=0,016 ; \mathrm{p}<0,05)$. The rate of blood type $\mathrm{AB} \mathrm{Rh}(-)$ was higher in the $\mathrm{SC}$ subgroup than AC and SCC group.

A statistically significant association was detected between pathological results and blood group A when $\mathrm{Rh}$ factor was excluded $(p=0,010 ; p<0,05)$. The rate of blood type A was higher in AC and SCC groups than SC group. Furthermore, there was no statistically significant association between pathological results and $\mathrm{Rh}$ factor in terms of subtypes $(\mathrm{p}>0,05)$.

Urun et al. reported in their study conducted in 2013 that the blood groups other than blood group $\mathrm{O}$ and $\mathrm{Rh}(-)$ blood groups increase the risk of lung cancer. Furthermore, they reported that blood group $\mathrm{O}$ and $\mathrm{Rh}(+)$ blood type were associated with lower risk of lung cancer by $14 \%$ and $13 \%$, respectively (6). The findings stated above are consistent with our findings when $\mathrm{Rh}$ factor was solely excluded. In contrast to findings of the present study and other studies, however, a recent study conducted by Alqudah et al. reported that the individuals with $\mathrm{Rh}(+)$ blood type have higher risk for lung cancer (19).

Chrysanthkapoulos et al. performed a study on Greek adults and stated no association between ABO blood group types and lung cancer (16). However, Vasan et al. (26) reported an association of blood groups other than group $\mathrm{O}$ with risk of lung cancer in their study in 2016. 
Our findings were consistent with those of Vasan et al. Different from other studies, we observed that blood group B $\mathrm{Rh}(-)$ displays more risk in terms of SCLC.

Another recent study conducted by Biswas et al. detected a higher rate of Rh (-) status in patients with SCLC than all other subtypes of lung cancer (27).

There are some papers focusing on the relation between prognosis of lung cancer and blood groups. It was observed in a study where 81 patients with non-metastatic local-advanced NSCLC were reviewed that blood group ABO does not have a significant effect on prognosis (28). On the other hand, Lee et al. reported that the patients with blood group A have a better prognostic value than other blood groups (8). Similarly, Graziono et al. stated that antigen $\mathrm{A}$ indicates a lower survival rate in the patients with lung cancer (29). Expression of blood group antigen A was found as a positive prognostic factor in a recent study conducted by Franchini et al. (30).

Although the association between lung cancer and blood groups has not been clarified in the literature yet, research is being conducted on this topic. A complete consensus was not reached on this issue. We wanted to make a contribution to such non-clarified issue with the present study.

\section{CONCLUSIONS}

We have observed an association between risk of lung cancer and ABO blood groups; however, Rh factor is not solely effective. There is an association of risk between non-O groups and lung cancer. Furthermore, the patients with B Rh (-) were found risky in terms of SCLC. Close monitoring of the patients under risk may be required. A detailed examination of the association of blood group subtypes with lung cancer cells at molecular level would be useful to clarify the association between lung cancer and blood groups.

\section{Conflict of Interest}

The authors declared no conflicts of interest during the preparation and publication of this manuscript.

\section{Acknowledgement}

Authors thank Prof. Dr. Tahir Sevval Eren and Dr. Zeynep Bilgi for generous help and support during drafting and revision of this manuscript.

Author's Contributions: Idea/Concept: A.G.A.; Design: A.G.A., İ.N.Ö.; Data Collection and/or Processing: İ.N.Ö; Analysis and/or Interpretation: C.E.; Literature Review: A.G.A; T.Ş.E.; Writing the Article: C.E.; Critical Review: A.G.A.,I.N.Ö., C.E., T.Ş.E.

\section{REFERENCES}

1. Jemal A, Bray F, Center MM, Ferlay J, Ward E, Forman D. Global cancer statistics. CA Cancer J Clin. 2011; 61(2): 69-90.

2. Ferlay J, Soerjomataram I, Dikshit R, Eser S, Mathers C,Rebelo M, et. al. Cancer incidence and mortality worldwide: sources, methods and major patterns in GLOBOCAN 2012. Int J Cancer. 2015; 136 (5): E359-86.

3. Dela Cruz Cs, Toune LT, Matthay RA. Lung Cancer: Epidemilogy, etiology, and prevention. Clin Chest Med. 2011; 32 (4): 605-44.
4. Couraud S, Zalcman G, Milleron B, Morin F, Souquet PJ. Lung cancer in never smokers-a review. Eur J Cancer. 2012; 48(9): 1299-311.

5. Hakomori S. Tumor-associated carbohydrate antigens defining tumor malignancy:basis for development of anticancer vaccines. Adv Exp Med Biol. 2001; 491: 369-402.

6. Urun Y, Utkan G, Cangir AK, Oksuzoglu OB, Ozdemir N, Oztuna DG, et al. Asian Pac J Cancer Prev. 2013; 14 (5): 2801-3.

7. Alvarez-Fernandez E, Carretero-Albinana L. Expression of blood group antigens by normal bronchopulmonary tissues and common forms of pulmonary carcinomas. Arch Pathol Lab Med. 1991; 115(1): 42-9.

8. Lee JS, Ro JY, Sahin AA, Hong VK, Brown WB, Mountain $\mathrm{CF}$, et al. Expression of blood-group antigen A-a favorable prognostic factor in non-smallcell lung cancer. N Engl J Med. 1991; 324(16): 1084-90.

9. Cerny T, Fey M, Oppliger R, Castiglione M, Nachbur B, Gertsch M, et al. Prevalence of the rhesus-negative phenotype in Caucasian patients with small-cell lung cancer (SCLC). Int J Cancer. 1992; 52(3): 504-6.

10. Miyake M, Taki T, Hitomi S, Hakomori S. Correlation of expression of $\mathrm{H} / \mathrm{Le}(\mathrm{y}) / \mathrm{Le}(\mathrm{b})$ antigens with survival in patients with carcinoma of the lung. N Engl J Med. 1992; 327(1): 14-8.

11. Gwin JL, Klein-Szanto AJ, Zhang SY, Agarwal P, Rogatko A, Keller SM. Loss of blood group antigen A in non-small cell lung cancer. Ann Surg Oncol. 1994; 1: 423-7.

12. Ulger AF, Keklik T, Kumbasar OO, Arbak P, Demirkazik A,Gungor A, et al. Prognostic significance of blood group antigen expression of tumor tissue in lung cancer patients. Tumori. 2002; 88(5): 395-9.

13. Sanchez-Mora N, Cebollero PM, Monroy V, Herranz Aladro M, Alverez-fernandez V. Expression of histoblood group antigens in bronchial squamous metaplasia. Eur Respir J. 2007; 29(2): 268-72.

14. Suadicani P, Hein HO, Gyntelberg F. ABO phenotypes and inflammation-related predictors of lung cancer mortality: the Copenhagen male study-a 16-year follow-up. Eur Respir J. 2007; 30(1): 13-20.

15. $\mathrm{P}$ Leon-Atance $\mathrm{P}$, Moreno-Mata N, GonzalezAragoneses F, Canizares-Carretero MA, PobletMartínez E, Genoves-Crespo M, et al. Prognostic influence of loss of blood group A antigenexpression in pathologic stage I non-smallcell lung cancer. Arch Bronconeumol. 2012; 48(2): 49-54.

16. Chrysanthakopoulos NA, Dareioti NS. ABO blood group and the risk of lung cancer in Greek adults: a case-control study experimental oncology. Exp Oncol. 2018; 40: 249-50.

17. Fukumoto K, Taniguchi T, Usami N, Kawaguchi K, Fukui T, Ishiguro F, et al. The ABO blood group is an independent prognostic factor in patients with resected non-small cell lung cancer. J Epidemiol. 2015; 25(2): 110-6. 
18. Oguz A, Unal D, Tasdemir A, Karahan S, Aykas F, Mutlu $\mathrm{H}$, et al. Lack of any association between blood groups and lung cancer, independent of histology. Asian Pac J Cancer Prev. 2013; 14(1): 453-6.

19. Alqudah M, Allouh M, Hamouri S, Zaitoun A, Al Ghamdi N. Is Rh positivity a possible risk factor for lung cancer? JJBS. 2018; 11(3): 281-4.

20. Humphray SJ, Oliver K, Hunt AR, Plumb RW, Loveland JE, Howe KL, et al. DNA sequence and analysis of human chromosome 9. Nature. 2004; 429(6990): 369-74.

21. Dall'olio F. Protein glycosylation in cancer biology: An overview. Clin Mol Pathol 1996; 49(3): 126-35.

22. Wolpin BM, Chan AT, Hartge P, Chanock SJ, Kraft $\mathrm{P}$, Hunter DJ, et al. ABO blood group and the risk of pancreatic cancer. J Natl Cancer Inst. 2009; 101(6): 424-31.

23. Edgren G, Hjalgrim H, Rostgaard K, Norda R, Wikman A, Melbye M, et al. Risk of gastric cancer and peptic ulcers in relation to ABO blood type: a cohort study. Am J Epidemiol. 2010; 172(11): 12805.

24. Joh HK, Cho E, Choueiri TK. ABO blood group and risk of renal cell cancer. Cancer Epidemiol. 2012; 36(6): 528-32.

25. Urun Y, Utkan G, Yalcin S, Coskun HS, Kocer M, Özdemir NY, et al. Lack of any relationship between $\mathrm{ABO}$ and $\mathrm{Rh}$ blood groups and clinicopathological features in patients with gastrointestinal stromal tumors: Turkish Oncology Group. Asian Pac J Cancer Prev. 2012; 13(8): 4129-31.

26. Vasan SK, Hwang J, Rostgaard K, Nyren O, Ullum $\mathrm{H}$, Pedersen OBV, et al. ABO blood group and risk of cancer: A register-based cohort study of 1.6 million blood donors. Cancer Epidemiol. 2016; 44: 40.

27. Biswas A, Jiang Y, Li D, Mehta HJ, Kaye F. The prevalence of rhesus-negative blood group among patient with small cell lung cancer and analysis of its effect on overall survival. Front Oncol. 2018; 8(358): $1-4$.

28. Unal D, Eroglu C, Kurtul N, Oguz A, Tasdemir A, Kaplan B. ABO blood groups are not associated with treatment response and prognosis in patients with local advanced non- small cell lung cancer. Asian Pac J Cancer Prev. 2013; 14(6): 3945-8.

29. Graziano SL, Tatum AH, Gonchoroff NJ, Newman NB, Kohman LJ. Blood group antigen A and flow cytometric analysis in resected early-stage non-small cell lung cancer. Clin Cancer Res. 1997; 3(1): 87-93.

30. Franchini M, Liumbruno GM, Lippi G. The prognostic value of $\mathrm{ABO}$ blood group in cancer patients. Blood Transfus. 2016; 14(5): 434-40. 